\title{
Anti-inflammatory and analgesic activities of Hypericum brasiliense (Willd) standardized extract
}

\section{Fábio F. Perazzo, ${ }^{*, 1,2}$ Leonardo M. Lima, ${ }^{1}$ Marina de Mesquita Padilha, ${ }^{1}$ Leandro M. Rocha, ${ }^{3}$ Pergentino J. C. Sousa, ${ }^{4}$ José Carlos T. Carvalho ${ }^{1}$}

\author{
${ }^{1}$ Laboratório de Pesquisa em Fármacos, Universidade Federal do Amapá, Rod. JK, km 02, Marco Zero, \\ 68902-280 Macapá-AP, Brazil, \\ ${ }^{2}$ Laboratório de Bioquímica, Universidade do Estado do Amapá. Avenida Presidente Vargas, 650, \\ 68900-070 Macapá-AP, Brazil, \\ ${ }^{3}$ Laboratório de Tecnologia de Fitoterápicos, Faculdade de Farmácia, Universidade Federal Fluminense, Rua \\ Mario Viana, 523, Santa Rosa, 24241-000 Niterói-RJ, Brazil, \\ ${ }^{4}$ Laboratório de Farmacodinâmica, Faculdade de Farmácia, Universidade Federal do Pará, 66075-970 \\ Belém-PA, Brazil
}

\begin{abstract}
RESUMO: "Atividades anti-inflamatória e analgésica de extratos padronizados de Hypericum brasiliense (Willd)". As atividades antiinflamatória e antinociceptiva do extrato padronizado de Hypericum brasiliense (HBSE) (Guttiferae) foi avaliada em modelos animais. Ratos Wistar machos foram tratados com extrato de $H$. brasiliense $(50,250$ e $500 \mathrm{mg} / \mathrm{kg}$, v.o.) em solução 3\% Tween 80 0,9\% NaCl. O tratamento com HBSE (500 mg/kg) mostrou inibição significativa sobre o edema induzido por carragenina comparado ao grupo controle. Nessa dose, o edema foi reduzido em $31,25 \%$ na terceira hora (pico do edema) após o tratamento, mas na dose de $50 \mathrm{mg} / \mathrm{kg}$, o edema apresentou redução de $53,13 \%(\mathrm{p}<0,05)$. Ainda com a dose de $50 \mathrm{mg} /$ $\mathrm{kg}$, a diminuição do edema induzido por dextrana foi similar ao controle positivo, ciproeptadina. Houve diminuição na formação do tecido granulomatoso $(6,6 \%)$ comparável ao grupo controle. O HBSE também inibiu o número de contorções abdominais em 46,4\%, estatisticamente igual ao controle positivo, tratado com indometacina (42,9\%). Na dose de $250 \mathrm{mg} / \mathrm{kg}$, houve inibição do número de contorções em $70,7 \%$ quando comparado ao grupo controle $(p<0,001)$. No teste da placa-quente, foi verificado aumento no tempo de latência com a dose de $50 \mathrm{mg} / \mathrm{kg}$. Os resultados demonstram que o HBSE possui atividade antiinflamatória sobre processos agudos, principalmente quando sua gênese está relacionada à síntese dos derivados do ácido araquidônico, e seu efeito analgésico provavelmente envolve ação sobre o Sistema Nervoso Central.
\end{abstract}

Unitermos: Hypericum brasiliense, Guttiferae, antiinflamatório, analgésico, SNC.

\begin{abstract}
The anti-inflammatory and antinociceptive activities of the standardized leaves extract (HBSE) of Hypericum brasiliense (Guttiferae) were evaluated in animal models. Male Wistar rats were treated with $H$. brasiliense extract (50, 250 and $500 \mathrm{mg} / \mathrm{kg}$, p.o.) in $3 \%$ Tween 80 $0.9 \%$ saline solution. The treatment of the edema induced by carrageenin with HBSE $(500 \mathrm{mg} /$ $\mathrm{kg}$ ) showed significant inhibition when compared to the control group. At this dose, the edema decreased by $31.25 \%$ in the third hour after treatment (edema peak), but the dose of $50 \mathrm{mg} / \mathrm{kg}$ has inhibited the edema by $53.13 \%(\mathrm{p}<0.05)$. At the dose of $50 \mathrm{mg} / \mathrm{kg}$, the decrease of the edema induced by dextran was similar to that caused by cyproheptadine. The decrease of the formation of granulomatous tissue $(6.6 \%)$ was comparable to the control group. The HBSE inhibited the abdominal constrictions induced by acetic acid. At a dose of $50 \mathrm{mg} / \mathrm{kg}$, the inhibition of the abdominal constrictions $(46.4 \%)$ was comparable to that produced by indomethacin $(42.9 \%)$. A dose of $250 \mathrm{mg} / \mathrm{kg}$ inhibited these constrictions by $70.66 \%$ when compared to control $(\mathrm{p}<0.001)$. In the hot-plate test, an increase in the latency time was observed at a $50 \mathrm{mg} / \mathrm{kg}$ dose. These data suggest that HBSE has anti-inflammatory activity on acute process, developed principally by arachdonic acid derivates and analgesic effect due to its probable involvement in the Central Nervous System.
\end{abstract}

Keywords: Hypericum brasiliense, Guttiferae, anti-inflammatory, antinociceptive, CNS. 


\section{INTRODUCTION}

Plants belonging to the genus Hypericum (Guttiferae) are well known for their use as antidepressant (Harrer \& Schulz 1994; Linde et al., 1996; Vorbach et al., 1997; Wheatly, 1997; Volz, 1997), analgesic (Apaydin et al., 1999), spasmolytic (Jakovljevie et al., 2000; Viana et al., 2007), among other applications (Nepomuceno et al., 2005; Cordeiro et al., 2005; Fritz et al., 2007).

$H$. brasiliense is an annual bush, known in Brazilian folk medicine as "milfacadas" or "alecrim bravo". Phloroglucinols, flavonoids and xanthones were found in this specie, as well as in $H$. perforatum (Rocha et al., 1995).

The aerial parts of $H$. perforatum have been described to show anti-inflammatory properties due to their inhibitory effects in the expression of proinflammatory genes like cyclooxygenase-2 (COX2 ), interleukin-6 and inducible nitric-oxide synthase (iNOS), by down-regulation of the DNA binding of the transcription factor signal transducer and activator of transcription-1 $\alpha$ (STAT-1 $\alpha$ ), but not of nuclear factor$\kappa \mathrm{B}$ (Tedeschi et al., 2003).

Miller (1998) showed that out of many species used traditionally as anti-inflammatory, only a few have been known for this action. Hyperforin, the major lipophilic compound found in $H$. perforatum and other Hypericum species, has been shown to be able to inhibit 5-lipoxygenase (5-LO) formation (IC50 values of about 1-2 $\mu \mathrm{M})$ and suppressed products with equal potency to the well-documented 5-LO inhibitor zileuton (Dana et al., 2002). Hyperforin, at nanomolar concentrations, induced significant inhibition of various ion channels (such as P-type $\mathrm{Ca} 2+$ channels) via interaction with calmodulin or through calmodulin-activated pathways involving at least one second messenger (Krishtal et al., 2001). H. perforatum significantly inhibited the edema induced by carrageenin and $\mathrm{PGE}_{1}$ in rats (Shipochliev et al., 1981), may be due to the mechanisms explained above. Western blot analyses showed that in-vivo treatment with $H$. perforatum extract could modulate lipopolysaccharide and interferon- $\gamma$ induced COX-2 and inducible iNOS expression in peritoneal macrophages (Raso et al., 2002).

Dried and lyophilized methanol extracts of other species, $H$. lalandii (Recio et al., 1995) and $H$. triquetrifolium (Ozturk et al., 2002), were able to decrease the edema induced by carrageenin in rats as well. H. empetrifolium methanol extract (Trovato et al., 2001) exhibited significant anti-inflammatory and analgesic effects, showing that this extract was active against inflammatory pain.

Pre-clinical studies have demonstrated that the extract of Hypericum brasiliense has low toxicity at doses under 1,000 mg/kg (Rieli et al., 2002).

In this paper, we report the evaluation of possible anti-inflammatory and antinociceptive activities of a standardized extract of Hypericum brasiliense (Willd).

\section{MATERIAL AND METHODS}

\section{Hypericum brasiliense Willd standardized extract}

Leaves of Hypericum brasiliense (Willd) were collected in the State of Rio de Janeiro, Brazil, identified by Dr. Leandro Machado Rocha, of Universidade Federal Fluminense (UFF), Niterói, RJ, Brazil. The standardized extract was prepared by selective extraction of flavonoid compounds and xanthone derivates as described earlier (Rocha et al., 1995).

\section{Animals}

Wistar male rats (Rattus norvegicus) and Swiss male albino mice (Mus musculus) weighing between $180 \mathrm{~g}-200 \mathrm{~g}$ and $20 \mathrm{~g}-25 \mathrm{~g}$ respectively, were used in the experiments for anti-inflammatory and analgesic activities. The animals were acquired from the Biotery of the Universidade do Amapá (UNIFAP) and were kept in polyethylene boxes $(n=5)$, in acclimatized environment $\left(25 \pm 4{ }^{\circ} \mathrm{C}\right)$, light/dark control each 12 hours $(7$ a.m. to 7 p.m.). They were kept without food 12 hours prior to the experiments, and water was ad libitum. The local Bioethical Committee approved the assay protocols.

\section{Anti-inflammatory evaluation}

\section{Carrageenin-induced rat paw edema}

The method used was described by Winter et al. (1962) and modified by Carvalho et al. (1999). Thirty minutes after oral administration of HBSE (50 and $500 \mathrm{mg} / \mathrm{kg}$ p.o.), $0.1 \mathrm{ml}(1000 \mu \mathrm{g} / \mathrm{paw})$ of carrageenin (Iota-Fluka-Biochemika Co.) was injected into the right paw and $0.1 \mathrm{ml}$ of saline $0.9 \%$ solution into the left paw. The measurement of paw volume was taken during a four-hour period after the stimulus application, using a Plethysmometer (Ugo Basile, Mod. 7540). The inhibition of the inflammation was calculated by measuring the volume difference between the right and left paws in comparison to the control group (3\% Tween $800.9 \%$ saline solution, p.o.) and the group treated with indomethacin $(10 \mathrm{mg} / \mathrm{kg}$, p.o., MSD Co.), used as a standard drug for anti-inflammatory activity.

\section{Dextran-induced rat paw edema}

The method used was described by Carvalho et al. (1999). Thirty minutes after oral administration of HBSE (50 and $500 \mathrm{mg} / \mathrm{kg}$ p.o.), $0.1 \mathrm{ml}(100 \mu \mathrm{g} / \mathrm{paw})$ of dextran (T-70 MW, 70000 Pharmacia) was injected into the right paw and $0.1 \mathrm{ml}$ of saline solution $(0.9 \%)$ into the left paw. The measurement of paw volume was taken at the second hour after the stimulus. The inhibition of the 
inflammation was calculated by measuring the volume difference between the right and left paws in comparison to the control group (3\% Tween $800.9 \%$ saline solution, p.o.) and the group treated with cyproheptadine $(10 \mathrm{mg} /$ $\mathrm{kg}$, p.o.), used as a standard drug for anti-inflammatory activity.

\section{Granulomatous tissue formation}

This assay was described by Niemegeers et al. (1975), Swingle \& Shideman (1972) and Meier et al. (1950). Pellets weighing approximately $40 \mathrm{mg}$ each were made with $5 \mathrm{~mm}$ of dental cotton tampon. The pellets were sterilized and then impregnated with $0.4 \mathrm{ml}$ ampicillin aqueous solution at the moment of implantation. Having the animals anaesthetized, the pellets were subcutaneously introduced, through abdominal skin incision. The HBSE group was daily treated (50 and $250 \mathrm{mg} / \mathrm{kg}$ ), for six consecutive days. The second group was treated, during a six-day period, with dexamethasone (2 $\mathrm{mg} / \mathrm{kg}$, topically, MSD Co.). The third group (control) was treated daily, for six consecutive days, with $0.5 \mathrm{ml}$ of distilled water (p.o.). This treatment was initiated 2 hours following the implantation of pellets and continued until the sixth day. In the seventh day, the animals were sacrificed and the granulomas removed, dried for 24 hours $\left(60{ }^{\circ} \mathrm{C}\right)$ and the weigh determined. The difference between the initial and final weighs was considerate the weigh of the produced granulomatous tissue.

\section{Analgesic activity evaluation}

\section{Writhing test in mice}

This test was based on the method described by Koster et al. (1959). Groups of mice $(n=8)$ were orally treated with 50 and $250 \mathrm{mg} / \mathrm{kg}$ HBSE doses 30 minutes before intraperitoneal injection of $0.6 \%(\mathrm{v} / \mathrm{v})$ acetic acid solution $(0.25 \mathrm{ml} /$ animal $)$. Indomethacin was used as the standard drug (10 mg/kg, p.o.). The number of muscular contractions was counted during 20 minutes, starting on the 5 th minute after the stimulus. Data represent average of the total number of writhes observed.

\section{Hot-plate test}

The hot-plate test described by Jacob et al. (1974) was used. The animals were placed on an aluminum plate with controlled temperature $(50 \pm$ $0.5{ }^{\circ} \mathrm{C}$, Model DS37 Socrel, Ugo Basile - Italy). The reaction time was noted by observing either the licking of the hind paws or the rotation movements at $0,30,60$, 90 and 120 min after oral administration of HBSE in the doses of 50 and $250 \mathrm{mg} / \mathrm{kg}$. Morphine $(4 \mathrm{mg} / \mathrm{kg}$, p.o., Cristália Co.) was used as reference drug.

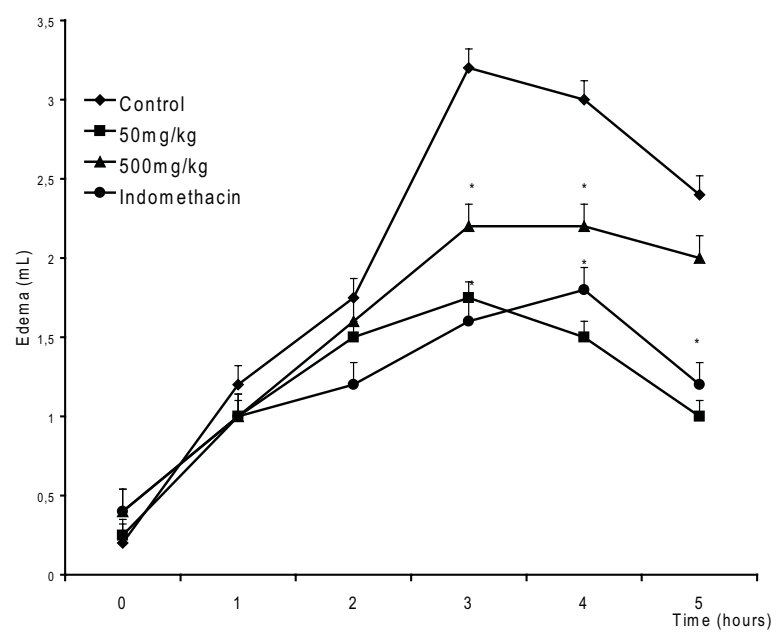

Figure 1. Effect of HBSE oral administration $(50$ and $500 \mathrm{mg}$ / $\mathrm{kg}$ ) and indomethacin $(10 \mathrm{mg} / \mathrm{kg}$, p.o.) on the edema induced by carrageenin $(1000 \mu \mathrm{g} / \mathrm{paw})$. *ANOVA followed by Dunnet's test, with $\mathrm{p}<0.05$. Data are expressed as Media \pm S.E.M. $\mathrm{n}=$ 6/group.

\section{Rota-rod test}

The method used was according to the one described by Perazzo et al. (2004). Groups of 8 rats were previously selected for their ability to successfully remain on the revolving bar of a Rota-rod apparatus over a 2-minute period. These animals were treated with the dose of HBSE (250 mg/kg, p.o.) or 3\% Tween $800.9 \%$ saline solution and tested on the Rota-rod at $15 \mathrm{~min}$ intervals up to 3 hours after treatment. The parameter registered was the time spent on the bar at the different time intervals.

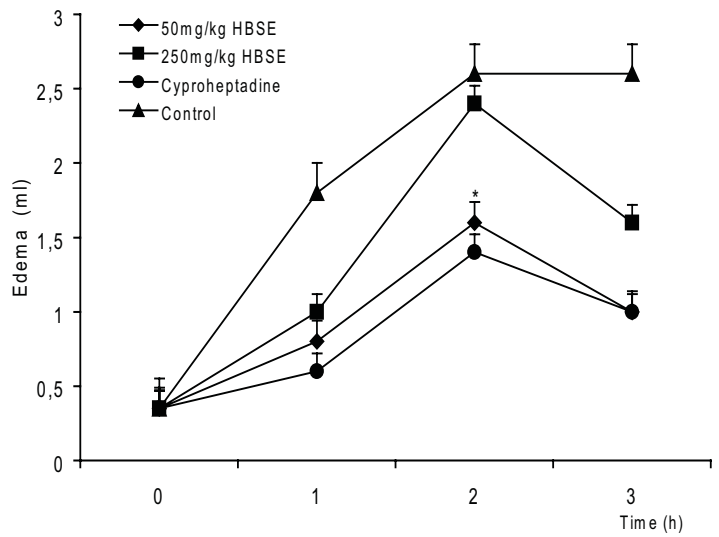

Figure 2. Effect of HBSE oral administration $(50$ and $500 \mathrm{mg} /$ $\mathrm{kg}$, p.o.) and cyproheptadine $(10 \mathrm{mg} / \mathrm{kg}$, p.o.) in the rat paw edema induced by dextran $(100 \mu \mathrm{g} / \mathrm{paw}) . *$ ANOVA followed by Dunnet's test, with $\mathrm{p}<0.05$. Data are expressed as Media \pm S.E.M. $n=6 /$ group.

\section{Statistical analysis}

The statistical analysis was carried out using 


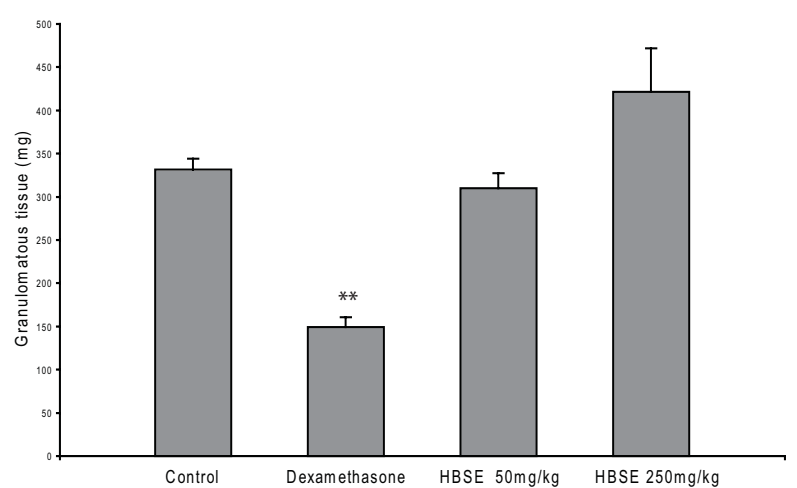

Figure 3. Effect of HBSE oral administration (50 and 250 $\mathrm{mg} / \mathrm{kg}$, p.o.) and dexamethasone $(0.5 \mathrm{mg} / \mathrm{kg}$, topically) in the granulomatous tissue formation. *ANOVA followed by Dunnet's test. ${ }^{* *} \mathrm{p}<0.01$. Data are expressed as Media \pm S.E.M. $n=6 /$ group.

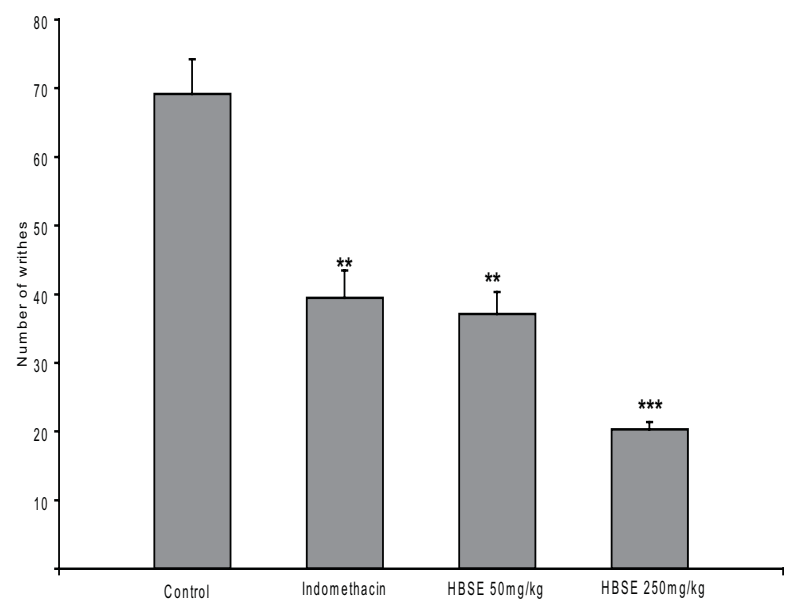

Figure 4. Effect of HBSE oral administration (50 and $250 \mathrm{mg} /$ $\mathrm{kg}$, p.o. $)$ and indomethacin $(10 \mathrm{mg} / \mathrm{kg}$, p.o. $)$ in the writhing test. *ANOVA followed by Dunnet's test, with $* * \mathrm{p}<0.01$ and $* * * \mathrm{p}$ $<0.001$. Data are expressed as Media \pm S.E.M. $\mathrm{n}=8$ /group.

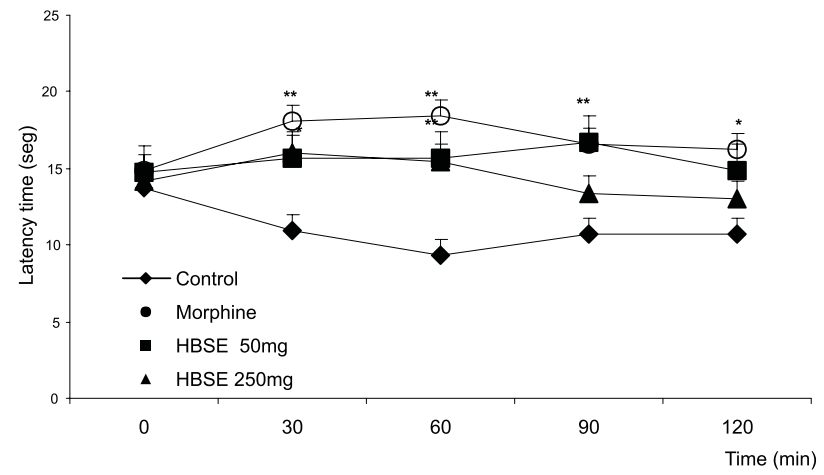

Figure 5. Effect of HBSE oral administration (50 and $250 \mathrm{mg}$ / $\mathrm{kg}$, p.o.) and morphine $(4 \mathrm{mg} / \mathrm{kg}$, p.o.) on the hot-plate test. *ANOVA followed by Dunnet's test, with **p $<0.01$ and $* * * p$ $<0.001$. Data are expressed as Media \pm S.E.M. $\mathrm{n}=8$ /group.

one-way ANOVA followed by Dunnet's test. Results with $\mathrm{p}<0.05$ were considered statistically significant.
Data are expressed as Media + S.E.M. (Sokal \& Rohlf, 1995).

\section{RESULTS}

\section{Rat paw edema}

In the assay induced by carrageenin, the treatment with $500 \mathrm{mg} / \mathrm{kg}$ of HBSE produced a statistically significant reduction when compared with the control ( $\mathrm{p}<0.05)$. In the third hour (edema peak), the reduction was $31.25 \%$. The $50 \mathrm{mg} / \mathrm{kg}$ dose decreased the volume by $53.13 \%$ when compared to the control (p $<0.05)$, as shown in Figure 1.

In the edema induced by dextran, HBSE decreased the edema with $50 \mathrm{mg} / \mathrm{kg}$ dose when compared to the control. This result was not statistically significant when compared to the group treated with cyproheptadine (Figure 2).

\section{Granulomatous tissue induction}

The treatment with HBSE did not reduce the granulomatous tissue formation. The $50 \mathrm{mg} / \mathrm{kg}$ dosage inhibited the granulomatous tissue formation by $6.6 \%$ when compared to control group (Figure 3)

\section{Writhing test in mice}

The HBSE inhibited the writhing process induced by acetic acid in a dose-dependant manner. The $50 \mathrm{mg} / \mathrm{kg}$ dose produced an inhibition comparable to that caused by indomethacin, and these were $46.4 \%$ and $42.9 \%$ respectively $(\mathrm{p}<0.01)$. The $250 \mathrm{mg} / \mathrm{kg}$ dosage inhibited the writhing by $70.66 \%$ when compared to the control group $(p<0.001)$ as shown in the Figure 4.

\section{Hot plate test}

HBSE, at a dose of $50 \mathrm{mg} / \mathrm{kg}$, increased the latency time of the animals by $42.4 \%$ (30 $\mathrm{min}$ ), $68.1 \%$ (60 $\mathrm{min})$ and $55.6 \%$ (90 $\mathrm{min})$. Morphine, used as the positive control, increased the latency time by $64.3 \%$ (30 $\mathrm{min}), 97.6 \%$ (60 $\mathrm{min}$ ) and $52.1 \%$ (90 $\mathrm{min})$, as shown in the Figure 5.

\section{Rota-rod test}

In the rota-rod assay, there was no significant difference $(p>0.05)$ between the group treated with HBSE and the control group at the dose tested during the observation period ( 3 hours).

\section{DISCUSSION}

The genus Hypericum has been used worldwide to treat pain, inflammation and specially depression 
(Harrer \& Schulz, 1994; Linde et al., 1996; Vorbach et al., 1997; Wheatly, 1997; Volz, 1997; Apaydin et al., 1999; Jakovljevie et al., 2000). It is a promising antiinflammatory drug in chronic diseases (Apaydin et al., 1999), as well as in acute process, which could be in part related to their modulation of COX-2 expression (Shipochliev et al., 1981). The major chemical compounds found in this species, such as dianthrones, naphthodianthrone, anthraquinone, emodin, hyperforin, hypericin and pseudohypericin caused inhibition of 12-lipoxygenase activity (Bezakova et al., 1999).

The Hypericum brasiliense standardized extract (HBSE) showed anti-inflammatory activity in the carrageenin-induced rat paw edema, which is an in vivo model commonly used for the assessment of this kind of activity (Winter et al, 1962; Carvalho et al., 1999). The HBSE $50 \mathrm{mg} / \mathrm{kg}$ dose inhibited the edema formation in the third hour after the stimulus application, when the arachdonic acid derivatives are actuating, principally $\mathrm{PGE}_{2} \alpha$ (Carvalho et al., 1999). This result could be due to an inhibitory effect on the expression of pro-inflammatory genes like COX-2, interleukin- 6 and inducible iNOS (Rocha et al., 1995). The edema induced by dextran is characterized by histamine and serotonin liberation in the first hour after stimulus application, increasing vascular permeability by binding in $\mathrm{H}_{1}$ and $5-\mathrm{HT}_{2}$ receptors located in endothelium (Trowbridge \& Emling, 1996). Non-steroidal substances are not able to inhibit this edema due to its mechanisms, which involves arachdonic acid derivatives (Merlos et al., 1990). At a dose of $50 \mathrm{mg} / \mathrm{kg}$, HBSE efficiently reduced this process. Raso et al. (2002) described the modulation of lipopolysaccharides production, interferon- $\gamma$ induced COX-2 and inducible iNOS expression in peritoneal macrophages by hyperforin, may explain the results found for HBSE.

The granulomatous tissue formation is a model to study the chronic effects of anti-inflammatory drugs (Ismail et al., 1997) and also allows quantifying this process (Swingle \& Shideman, 1972). The HBSE treatment did not inhibit the tissue formation, suggesting that this drug is not able to actuate in this experimental chronic process.

The HBSE showed peripheral analgesic activity by the results obtained with the writhing test and central effects by the data obtained with the hot-plate test. This inhibition should be due to central effects, but this did not induce loss of motor coordination (Trovato et al., 2001), as our group found on the rota-rod test. An antinociceptive effect by $H$. caprifolatum and $H$. polyanthemum mediated by the opioid system had been described (Viana et al., 2003). Moreover, this activity seems to depend on at least two chemical substances, which could be flavonoids belonging to quercetin group or dianthrones (Kumar et al., 2001).

Thermal stimulation excites the skin receptors, activating thermosensible and nociceptive fibers (Le
Bars et al., 2001). The treatment with HBSE has shown during the first 60 minutes, a central action in any dose and this effect has been more effective with the animals treated with $50 \mathrm{mg} / \mathrm{kg}$ doses. It is possible to suggest an analgesic action due to a central action with the data obtained with the hot-plate test after the treatment with HBSE and previous literature data.

The data presented above suggest that HBSE has an anti-inflammatory activity in acute process with the involvement of arachdonic acids derivatives. This can be attributed to the presence of major compounds such as flavonoids, dianthrones and hyperforin (which were detected in thin layer chromatography analysis) and analgesic action due to a possible central action.

\section{ACKNOWLEDGMENTS}

The authors are grateful Dr. Dhammika N. P. Nanayakkara (National Center for Natural Products Research, University of Mississippi (USA) for the English revision.

\section{REFERENCES}

Apaydin S, Zeybek U, Ince I, Elgin G, Karamenderes C, Ozturk B, Tuglular I 1999. Hypericum triquetrifolium Turra extract exhibits antinociceptive activity in the mouse. J Ethnopharmacol 67: 307-312.

Bezakova L, Psenak M, Kartnig T 1999. Effect of dianthrones and their precursors from Hypericum perforatum on lipoxygenase activity. Pharmazie 54: 711.

Carvalho JC, Sertie JA, Barbosa MV, Patrício KC, Caputo LR, Sarti SJ, Ferreira LP, Bastos JK 1999. Anti-inflammatory activity of the crude extract from the fruits of Pterodon emarginatus Vog. $J$ Ethnopharmacol 64: 127-133.

Cordeiro CHG, Chung MC, Sacramento LVS 2005. Interações medicamentosas de fitoterápicos e fármacos: Hypericum perforatum e Piper methysticum. Rev Bras Farmacogn 15: 272-278.

Dana A, Zundorf I, Dingermann T, Muller WE, Steinhilber D, Werz O 2002. Hyperforin is a dual inhibitor of cyclooxygenase and 5-lypoxygenase. Biochem Pharmacol 64: 1767-1775.

Fritz D, Bernardi AP, Haas JS, Ascoli BM, Bordignon SAL, von Poser G 2007. Germination and growth inhibitory effects of Hypericum myrianthum and H. polyanthemum extracts on Lactuca sativa L. Rev Bras Farmacogn 17: 44-48.

Harrer G, Schulz V 1994. Clinical investigation of the antidepressant effectiveness of Hypericum. J Geriatr Psych Neur 7: 6-8.

Ismail TS, Gapalakrisan S, Begum VH, Elango V 1997. Antiinflammatory activity of Salacia oblonga Wall and Azima tetracantha Lam. J Ethnophamacol 56: 145152.

Jacob JJC, Tremblay EC, Colome MC 1974. Facilitation the reactions nociceptive by naloxone in mice and rats. Psychopharmacol 37: 213-223.

Jakovljevic V, Popovic M, Mimica-Dukic N, Sabo A, Gvozde-

Rev. Bras. Farmacogn 
Novic I 2000. Pharmacodynamic study of Hypericum perforatum L. Phytomedicine 7: 449-453.

Koster R, Anderson M, De Beer EJ 1959. Acetic acid analgesic screening. Fed Proc 18: 418-420.

Krishtal O, Lozovaya N, Fisunov A, Tsinsadze I, Pankratov Y, Kopanitsa M, Chatterjee SS 2001. Modulation of ion channels in rat neurons by the constituents of Hypericum perforatum. Pharmacopsychiatry 34 (Suppl. 1): S74-S82.

Kumar V, Singh PN, Bhattacharya SK 2001. Anti-inflammatory and analgesic activity of Indian Hypericum perforatum L. Indian J Exp Biol 39: 339-343.

Le Bars D, Gozariu M, Cadden SW 2001. Animal models of nociception. Pharmacol Rev 53: 597-652.

Linde K, Ramirez G, Mulrow CD, Pauls A, Weidenhammer W, Melchart D 1996. St John's wort for depression - an overview and meta-analysis of randomized clinical trials. Brit Med J 313: 253-258.

Meier R, Schuler W, Desaulles P 1950. L-usnic acid: tumor inhibitor isolated from Lichens. Experimentia 6: 469-471.

Merlos MLA, Vericat L, Garcia-Rafanell J, Forn J 1990. Comparative study of the effect of CV-6209, a specific PAF-antagonist, on paw edema caused by different phlogogen agents. Pharmacology 40: 211217.

Miller AL 1998. St John's Wort (Hypericum perforatum): clinical effects on depression and other conditions. Altern Med Rev 3: 18-26.

Nepomuceno F, Las Casas L, Peters VM, Guerra MO 2005. Desenvolvimento embrionário em ratas tratadas com Hypericum perforatum durante o período de implantação. Rev Bras Farmacogn 15: 224-228.

Niemegeers CJE, Awouters F, Lenaerts FM, Janssen AJ 1975. The activity of suprofen on nystatin-induced paw edema in rats. Arzneimittel-Forsch 25: 1516-1519.

Ozturk B, Apaydin S, Goldeli E, Ince I, Zeybek U 2002. Hypericum triquetrifolium Turra. Extract exhibits anti-inflammatory activity in the rat. $J$ Ethnopharmacol 80: 207-209.

Perazzo FF, Carvalho JCT, Carvalho JE, Rehder VLG 2004. Central properties of the essential oil and crude ethanolic etract from aerial parts of Artemisia annua. Pharmacol Res 48: 497-502.

Raso GM, Pacilio M, Di Carlo G, Esposito E, Pinto L, Meli R 2002. In-vivo and in-vitro anti-inflammatory effect of Echinacea purpurea and Hypericum perforatum. J Pharm Pharmacol 54: 1379-1383.

Recio MC, Giner RM, Manez S, Rios JL, Marston A, Hostettmann K 1995. Screening of tropical medicinal plants for anti-inflammatory activity. Phytother Res 9: $571-574$

Rieli MF, Mattei R, Carlini EA 2002. Activity of Hypericum brasiliense and Hypericum cordatum on the central nervous system in rodents. Fitoterapia 73: 462-471.

Rocha LM, Marston A, Potterat O, Kaplan MA, StoeckliEvans H, Hostettmann K 1995. Antibacterial phloroglucinols and flavonoids from Hypericum brasiliense. Phytochemistry, 40:1447-1452.

Shipochliev T, Dimitrov A, Aleksandrova E. 1981. Antiinflammatory action of a group of plant extracts. Veteri Med Nauki 18: 87-94.
Sokal RR, Rohlf FJ 1995. Biometry. San Francisco 175-205; 404-486.

Swingle KF, Shideman FE 1972. Phases of inflammatory response to subcutaneous implantation of cotton pellet and other modifications by certain anti-inflammatory agents. J Pharmacol Exp Ther 183: 226-234.

Tedeschi E, Menegazzi M, Margotto D, Suziki H, Foerstermann U, Kleinert H 2003. Anti-inflammatory actions of St. John's wort: inhibition of human inducible nitricoxide syntahse expression by down-regulating signal transducer and activator of transcription-1 $\alpha$ (STAT$1 \alpha$ ) activation. J Pharmacol Exp Ther 307: 254261.

Trovato A, Raneri E, Kouladis M, Tzakou O, Taviano MF, Galati EM 2001. Anti inflammatory and analgesic activity of Hypericum empetrifolium Willd. (Guttiferae). Farmaco 56: 455-457.

Trowbridge HO, Emling RC 1996. Inflamação - Uma revisão do processo. 4a Edição, Brasil.

Viana AF, Heckler APM, Fenner R, Rates SMK 2003. Antinociceptive activity of Hypericum caprifoliatum and Hypericum polyanthemum (Guttiferae). Braz J Med Biol Res 36: 631-634.

Viana AF, Heckler APM, von Poser GL, Langeloh A, Rates SMK 2007. Efeito de Hypericum caprifoliatum Cham. \& Schltdl. (Guttiferae) sobre contrações em íleo isolado de cobaio induzidas por diferentes agonistas. Rev Bras Farmacogn 17: 378-383.

Volz HP 1997. Controlled clinical trials of Hypericum extracts in depressed patients - an overview. Pharmacopsychiatry 30: 72-76.

Vorbach EU, Arnoldt KH, Hubner WD 1997. Efficacy and tolerability of St John's wort extract LI 160 versus imipramine in patients with severe depressive episodes according to ICD. Pharmacopsychiatry 30: 81-85.

Wheatly D 1997. LI 160, an extract of St John's wort, versus amitriptyline in mildly to moderately depressed outpatients - a controlled 6-week clinical trial. Pharmacopsychiatry 30: 77-80.

Winter CA, Risley EA, Nuss GW 1962. Carrrageenaninduced edema in hind paw of rat as an assay for anti-inflammatory drugs. Prog Soc Biol Med 11: 544-547. 